\title{
Faktor Risiko yang Mempengaruhi Tingkat Keparahan Luka Tekan pada Lansia di Masyarakat
}

\section{Risk Factor Affecting the Severity of Pressure Ulcer in the Community-Dwelling older Adults}

\author{
Husneni Mukhtar1*, Sheizi Prista Sari², Eka Afrima Sari ${ }^{3}$ \\ 1) Fakultas Teknik Elektro, Telkom University, Indonesia \\ 2) Maastricht University, Netherlands \\ 3) Fakultas Ilmu Keperawatan, Universitas Padjadjaran, Indonesia \\ husneni.mukhtar@telkomuniversity.ac.id \\ DOI: http://doi.org/10.29080/jhsp.v3i1.187
}

\section{Kata Kunci}

Luka tekan

Skala Braden

Korelasi data

Lansia

\section{Keywords}

Pressure ulcer Braden scale Data correlation Elderly

\section{Abstrak}

Kejadian luka tekan pada lansia di rumah merupakan masalah global yang terus diupayakan untuk diminimalisir risikonya. Luka tekan pada lansia di rumah telah diketahui memiliki karakteristik yang berbeda dengan luka tekan yang terjadi pada pasien lansia di rumah sakit atau rumah perawatan. Tujuan penelitian ini adalah untuk mengidentifikasi faktor risiko dominan berdasarkan pengukuran skala Braden serta kekuatan hubungan diantara faktor risiko tersebut yang mempengaruhi keparahan luka tekan pada lansia di masyarakat. Penelitian ini merupakan penelitian potong lintang (cross sectional) terhadap 35 orang lansia yang memenuhi kriteria inklusi dan eksklusi dari 325 orang lansia di masyarakat yang ditemui dan dipilih secara acak. Data dianalisis dengan rumus korelasi Pearson menggunakan software Matlab. Hasil penelitian menunjukkan faktor dominan yang mempengaruhi tingkat keparahan luka tekan pada lansia di masyarakat adalah faktor aktivitas ( $\mathrm{r}=0.9437)$, mobilisasi $(\mathrm{r}=0.9200)$ dan gesekan ( $\mathrm{r}=0.8603)$. Sebaliknya, faktor kelembaban dan nutrisi memiliki hubungan paling rendah. Interaksi faktor gesekan dengan faktor aktivitas dan mobilitas sangat kuat mempengaruhi kejadian luka tekan pada lansia di masyarakat dengan nilai $r$ berturut turut adalah 0.8405 dan 0.8200 . Hasil penelitian merekomendasikan adanya upaya untuk meminimalkan faktor gesekan pada bagian tubuh lansia di masyarakat.

\section{Abstract}

The occurrence of pain ulcher (PU) in the elderly at home is a globally problem that continues to be sought to minimize the risk. Ulcer pain in the elderly at home has been known to have different characteristics with PU that occured in elderly patients in hospitals or nursing homes. The purpose of this study was to identify the dominant risk factors based on Braden scale measurements and the strength of the relationship between these risk factors that affect the severity of PU in the elderly in the community. This study was a cross-sectional study of 35 elderly people who met the inclusion and exclusion criteria of 325 elderly people in the community and randomly selected. Data were analyzed using the Pearson correlation formula using Matlab software. The results showed that the dominant factors affecting the severity of $P U$ in the elderly in the community were activity factors ( $r=0.9437)$, mobilization $(r=0.9200)$ and friction $(r=0.8603)$. In contrast, moisture and nutrition factors have the lowest relationship. The interaction among the factors of friction, activity and mobility is very strong affecting the incidence of $P U$ in the elderly in the community with $r$ values 0.8405 and 0.8200 , in respectively. The results of the study recommend that an effort to minimize friction factors in the body part of elderly in the community. 


\section{Pendahuluan}

Seiring dengan peningkatan usia harapan hidup, populasi penduduk berusia 60 tahun keatas atau yang disebut lanjut usia (lansia) juga meningkat secara signifikan World Health Organization (WHO) memprediksi jumlah lansia akan menjadi dua kali lipat pada tahun 2050 (1). Di Indonesia, jumlah lansia sudah melebihi 7\% sejak tahun 2015 sehingga menjadikan Indonesia sebagai salah satu negara dengan struktur penduduk menua (ageing population). Bahkan, jumlah lansia diprediksi mencapai 48.19 juta pada tahun 2035 (2).

Peningkatan populasi lansia membawa tantangan tersendiri dalam bidang kesehatan. Target untuk menjadikan lansia tetap sehat dan aktif telah menjadi fokus utama yang terbukti dengan lebih dari 3500 artikel ilmiah membahas tentang "healthy and successful aging" pada tahun 2016 (3). Meskipun demikian, proses penuaan tetap memicu terjadinya perubahan fisik, mental, sosial dan spiritual pada lansia sehingga juga meningkatkan risiko terjadinya berbagai masalah kesehatan (4-7). Di Indonesia, angka kesakitan lansia yang dilaporkan hampir mencapai 30\% namun tidak semuanya melakukan pemeriksaan ke pelayanan kesehatan (1). Hal ini berdampak pada adanya lansia sakit di rumah dengan atau tanpa akses pelayanan kesehatan yang memadai. Sebuah penelitian di Kota Bandung menunjukkan bahwa sebagian besar lansia di masyarakat memiliki satu atau lebih keluhan kesehatan dan hanya setengahnya melakukan akses terhadap pelayanan kesehatan (8). Jika lansia sakit tidak mendapatkan perawatan yang memadai maka akan menimbulkan komplikasi penyakit bahkan kematian $(9,10)$.

Salah satu komplikasi yang banyak ditemukan pada lansia sakit adalah luka tekan (Pressure Ulcer). Luka tekan merupakan luka yang terlokalisir pada kulit atau jaringan dibawahnya, biasanya pada area penonjolan tulang sebagai akibat dari penekanan atau kombinasi penekanan dan gesekan (11). Luka tekan biasanya menjadi perhatian tersendiri pada pasien-pasien yang dirawat di rumah sakit karena ini menjadi indikator baik atau buruknya kualitas pelayanan. Namun seiring dengan banyaknya lansia yang sakit di rumah, maka kejadian luka tekan di masyarakat mulai menjadi perhatian banyak pihak. Beberapa penelitian menunjukan angka kejadian luka tekan pada pasien-pasien sebelum masuk rumah sakit sebesar $3.3 \%$ sampai $11.1 \%$ dan sebagian besar terjadi pada lansia yang tinggal di rumah (12-14).

Sebuah penelitian terbaru di Indonesia menunjukan bahwa angka kejadian luka tekan pada lansia di rumah sebesar $10.8 \%$ (8). Lebih dari setengah luka (61.4\%) yang ditemukan pada responden adalah luka kategori 1 dan umumnya ditemukan pada area sekitar jari dan mata kaki serta lutut. Menariknya, karakteristik luka tekan seperti ini jarang ditemukan pada penelitian sebelumnya $(12,13,15-21)$. Oleh sebab itu, temuan ini perlu ditindaklanjuti agar kejadian luka tekan pada lansia di masyarakat, khususnya luka tekan kategori 1, dapat dikurangi angka kejadiannya. Luka tekan kategori 1 pada dasarnya dapat dicegah dengan tindakan sederhana asalkan faktor risikonya dapat dikenali sejak awal (11). Salah satu cara untuk mengenali risiko luka tekan adalah dengan mengukur menggunakan skala Braden. Skala Braden adalah sistem penilaian faktor risiko ulkus/ luka tekan yang paling banyak digunakan di dunia. Skala ini dikembangkan pada tahun 1987 oleh Barbara Braden dan Nancy Bergstrom dengan tujuan untuk membantu profesional kesehatan secara handal dapat menilai risiko pasien luka tekan (22). Namun sejauh ini, belum ada publikasi ilmiah yang menginformasikan tentang faktor risiko mana dari skala Braden yang menjadi faktor dominan terhadap kejadian luka tekan pada lansia di masyarakat.

Berdasarkan uraian diatas maka perlu dilakukan penelitian lebih lanjut untuk melihat faktorfaktor risiko yang mempengaruhi tingkat keparahan luka tekan pada lansia di masyarakat Indonesia. Dengan demikian, tujuan penelitian ini adalah untuk menganalisis faktor risiko dominan serta interaksi diantara faktor risiko tersebut terhadap tingkat keparahan luka tekan pada lansia di masyarakat berdasarkan pengukuran skala Braden.

\section{Metode Penelitian}

Penelitian ini dilakukan di Kota Bandung Provinsi Jawa Barat Indonesia menggunakan pendekatan potong lintang (cross sectional). Responden adalah lansia (berumur diatas 60 tahun) dengan kriteria inklusi tinggal di rumah dan menderita luka tekan, baik sedang berada dalam pengawasan petugas kesehatan atau tidak. Sedangkan kriteria eksklusi adalah lansia yang memiliki tanda-tanda vital (tekanan darah, nadi, respirasi dan suhu) yang tidak stabil. Dari 325 orang lansia yang dipilih secara acak sederhana berdasarkan daftar nama lansia yang tersedia di kantor kelurahan, didapatkan 35 orang lansia yang memenuhi kriteria inklusi dan eksklusi untuk diolah datanya lebih lanjut.

Data dikumpulkan selama satu bulan pada bulan Oktober-November 2017 oleh enam orang perawat yang telah lulus uji kompetensi nasional perawat. Penilaian luka tekan dilakukan dengan cara observasi langsung menggunakan kuesioner International Prevalence Measurement of Care Quality (LPZInternational) yang telah divalidasi kedalam bahasa Indonesia $(23,24)$. Kategori luka tekan ditetapkan berdasarkan standar rujukan National Pressure Ulcer Advisory Panel - European Pressure Ulcer Advisory Panel - Pan Pacific Pressure Injury Aliance (NPUAP-EPUAP-PPPIA) (11). Penilaian faktor risiko dilakukan menggunakan skala Braden $(25,26)$. Validitas dan reliabilitas skala Braden dalam Bahasa Indonesia juga 
sudah teruji dan dipublikasikan (23). Skor Skala Braden yang lebih rendah menunjukkan tingkat fungsi yang lebih rendah sehingga menyebabkan tingkat risiko ulkus tekan yang lebih tinggi.

Analisis data dilakukan untuk mengetahui hubungan antar faktor-faktor risiko yang digunakan pada penelitian ini melalui metode statistik analisis sederhana menggunakan software Matlab. Koefisien korelasi Pearson memberikan gambaran kekuatan hubungan antar faktor risiko skala Braden yang memiliki pengaruh dominan pada tingkat keparahan luka tekan pada responden. Perhitungan koefisien korelasi Pearson menggunakan persamaan (1),

$$
r=\frac{\sum_{i=1}^{n}\left(x_{i}-\bar{x}\right)\left(y_{i}-\bar{y}\right)}{\sqrt{\sum_{i=1}^{n}\left(x_{i}-\bar{x}\right)^{2} \sum_{i=1}^{n}\left(y_{i}-\bar{y}\right)^{2}}}
$$

Variabel $x$ dan $y$ berisi sebaran skala data pengamatan sebab terjadinya luka tekan yang terjadi. Dari keenam variabel dari faktor-faktor risiko yang terdapat pada skala Braden kemudian dianalisis faktor dominan yang mempengaruhi tingkat keparahan luka tekan yang dialami oleh lansia.

Berdasarkan nilai tabel critical values pada korelasi Pearson, maka nilai r-product untuk jumlah data $n=35$ dengan taraf signifikan sebanyak $5 \%$ adalah 0.334 . Dengan menggunakan nilai $r$ pembanding ini, variabel faktor-faktor risiko dijustifikasi apakah memiliki tingkat hubungan tinggi atau rendah terhadap tingkat keparahan luka tekan. Nilai koefisien korelasi yang kurang dari nilai r-product menunjukkan tidak adanya korelasi yang kuat antar variabel faktor risikonya. Sebaliknya, jika nilai koefisien korelasi lebih besar dari nilai $r$-product, maka variabel tersebut menunjukkan hubungan yang kuat dengan variabel lainnya. Nilai maksimum 1 menunjukkan korelasi dengan variabel dirinya sendiri. Hasil korelasi antar variabel menunjukkan nilai yang cukup baik diatas nilai $r$-product pada beberapa hubungan variabel dengan nilai target signifikan $5 \%$.

\section{Hasil Penelitian}

Karakteristik responden yang meliputi umur, jenis kelamin, status tinggal, warna kulit dan hasil penilaian skala Braden disajikan pada Tabel 1.

Tabel 1. Karakteristik Responden

\begin{tabular}{|c|c|c|c|c|c|c|c|}
\hline \multirow[b]{2}{*}{ Karakteristik Responden } & \multicolumn{6}{|c|}{ Kategori Luka Tekan } & \multirow[b]{2}{*}{$\begin{array}{c}\text { Total } \\
(\mathrm{n}=35)\end{array}$} \\
\hline & $\begin{array}{l}\text { PU Kat } 1 \\
(\mathrm{n}=18)\end{array}$ & $\begin{array}{l}\text { PU Kat } \\
2(n=5)\end{array}$ & $\begin{array}{c}\text { PU Kat } 3 \\
(n=9)\end{array}$ & $\begin{array}{l}\text { PU Kat } \\
4(n=0)\end{array}$ & $\begin{array}{l}\text { Unstageable } \\
(\mathrm{n}=0)\end{array}$ & $\begin{array}{l}\text { Susp. Deep } \\
\text { Tissue Injury } \\
(\mathrm{n}=3)\end{array}$ & \\
\hline Usia, th (Mean/SD) & $73.7(8.5)$ & $74(1.7)$ & $\begin{array}{l}78.5 \\
(8.2)\end{array}$ & - & - & $77.7(8.4)$ & $74.8(7.8)$ \\
\hline Perempuan, n (\%) & $\begin{array}{c}12 \\
(66.7 \%)\end{array}$ & $3(60 \%)$ & $\begin{array}{c}5 \\
(55.6 \%)\end{array}$ & - & - & $0(0 \%)$ & $20(57.1 \%)$ \\
\hline Status tinggal, n (\%) & & & & & & & \\
\hline a. Sendiri & $\begin{array}{c}2 \\
(11.1 \%)\end{array}$ & $0(0 \%)$ & $\begin{array}{c}1 \\
(11.1 \%)\end{array}$ & - & - & $0(0 \%)$ & $3(9 \%)$ \\
\hline b. Dengan pasangan & $\begin{array}{c}3 \\
(16.7 \%)\end{array}$ & $0(0 \%)$ & $0(0 \%)$ & - & - & $1(33.3 \%)$ & $4(11 \%)$ \\
\hline $\begin{array}{l}\text { c. Dengan pasangan } \\
\text { dan atau anak }\end{array}$ & $\begin{array}{c}3 \\
(16.7 \%)\end{array}$ & $2(40 \%)$ & $\begin{array}{c}1 \\
(11.1 \%)\end{array}$ & - & - & $0(0 \%)$ & $6(17 \%)$ \\
\hline Keluarga besar & $\begin{array}{c}10 \\
(55.6 \%)\end{array}$ & $3(60 \%)$ & $\begin{array}{c}7 \\
(77.8 \%)\end{array}$ & - & - & $2(66.7 \%)$ & $22(63 \%)$ \\
\hline
\end{tabular}

Berdasarkan Tabel 1 diketahui bahwa kejadian luka tekan pada umumnya ditemui pada lansia berusia 70 tahun keatas dan sebagian besar terjadi pada perempuan (57.1\%). Penilaian skala Braden berdasarkan tingkat keparahan luka responden disajikan dalam Tabel 2.

Tabel 2. Penilaian Skala Braden

\begin{tabular}{|c|c|c|c|c|c|c|c|}
\hline \multirow[b]{2}{*}{$\begin{array}{c}\text { Braden scale item, mean } \\
\text { (SD) }\end{array}$} & \multicolumn{6}{|c|}{ Kategori Luka Tekan } & \multirow[b]{2}{*}{$\begin{array}{c}\text { Total } \\
(\mathrm{n}=35)\end{array}$} \\
\hline & $\begin{array}{c}\text { PU Kat } 1 \\
(n=18)\end{array}$ & $\begin{array}{l}\text { PU Kat } \\
2(n=5)\end{array}$ & $\begin{array}{l}\text { PU Kat } \\
3(n=9)\end{array}$ & $\begin{array}{l}\text { PU Kat } \\
4(n=0)\end{array}$ & $\begin{array}{c}\text { Unstageable } \\
(n=0)\end{array}$ & $\begin{array}{c}\text { Susp. Deep } \\
\text { Tissue } \\
\text { Injury }(n=3)\end{array}$ & \\
\hline 1. Sensori persepsi & $3.5(0.7)$ & $3.3(1.2)$ & $3.3(0.5)$ & - & - & $3.7(0.6)$ & $3.1(0.8)$ \\
\hline Kelembaban & $3.2(0.4)$ & $2.7(0.6)$ & $3(0)$ & - & - & $3(0)$ & $3(0.6)$ \\
\hline Aktivitas & $3.1(0.8)$ & $2.7(1.5)$ & $3(0.6)$ & - & - & $2.3(0.6)$ & $2.4(1)$ \\
\hline Mobilitas & $3.5(0.9)$ & $2.7(1.5)$ & $3.2(0.8)$ & - & - & $2.3(0.6)$ & $2.6(1.1)$ \\
\hline Nutrisi & $3.6(0.7)$ & $3.7(0.6)$ & $4(0)$ & - & - & $3(1)$ & $3.4(0.8)$ \\
\hline Gesekan & $2.8(0.6)$ & $2.3(1.2)$ & $3(0)$ & - & - & $2.7(0.6)$ & $2.4(0.8)$ \\
\hline
\end{tabular}


Berdasarkan Tabel 2, dapat diketahui bahwa faktor risiko yang memiliki skala Braden terkecil adalah faktor aktivitas dan gesekan. Lebih jauh lagi, penelitian telah mengidentifikasi variabel-variabel dominan dan interaksi antar variabel yang mempengaruhi keparahan luka tekan pada lansia di masyarakat. Analisis koefisien korelasi pada variabel faktor risiko yang digunakan pada penelitian ini dibagi ke dalam dua bagian. Pertama adalah analisis korelasi setiap variabel terhadap jumlah penilaian tiap variabel untuk mengetahui kekuatan hubungan dari setiap variabel yang diuji; kedua adalah analisis korelasi antar variabel yang digunakan.

Secara umum koefisien korelasi antar variabel menunjukkan adanya keterhubungan antar variabelnya ( $r$ lebih besar dari $r$-product), seperti yang disajikan pada Gambar 1 . Berdasarkan Gambar 1 diketahui bahwa secara keseluruhan setiap variabel yang digunakan pada penelitian ini memiliki nilai yang cukup baik. Tiga variabel yang menunjukkan korelasi paling tinggi yaitu aktivitas ( $\mathrm{r}=0.9437)$, mobilisasi $(r=0.9200)$ dan gesekan $(r=0.8603)$. Namun, faktor risiko kelembaban menunjukkan korelasi yang paling rendah.

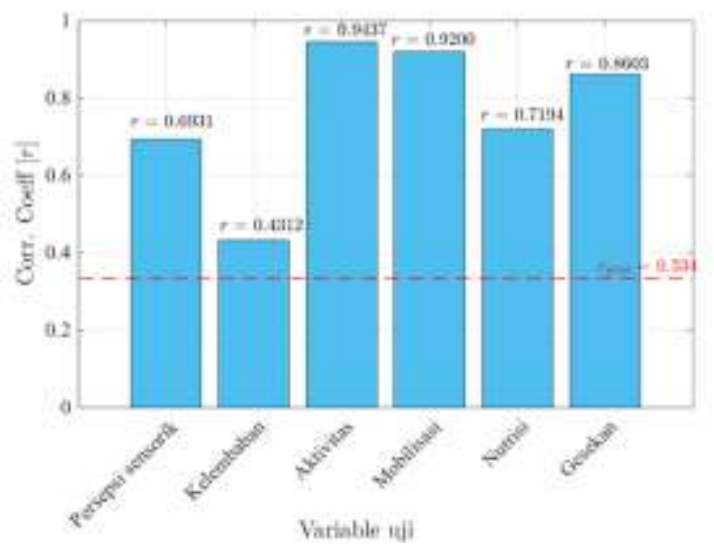

Gambar 1. Nilai koefisien korelasi variabel skala Braden. Garis putus-putus adalah nilai $r$-product moment dengan nilai target $5 \%$ dengan $n=35$ ( $r$-product $=0.334$ ). Bar chart menunjukkan nilai korelasi setiap variabel yang digunakan.

Pengujian interaksi antar variabel menggunakan persamaan (1) ditampilkan pada Tabel 3. Pada penelitian ini, variabel faktor risiko kelembaban merupakan variabel yang memiliki tingkat korelasi sangat lemah terhadap variabel lainnya yang ditunjukkan dengan rendahnya nilai koefisien korelasinya yang berkisar dari $r=0.1909$ sampai $r=0.2871$. Sedangkan korelasi variabel kelembaban dengan variabel nutrisi menghasilkan $r=0$, yang menunjukkan ketidak-adaan hubungan antar variabelnya. Sebaliknya, variabel faktor risiko aktivitas dan mobilisasi memiliki tingkat korelasi yang sangat tinggi terhadap variabel lainnya, dengan kisaran nilai koefisien korelasinya berturut-turut $r=0.6266-0.9205$ dan $r=$ $0.6309-0.8200$, terutama dengan variabel gesekan $(\mathrm{r}=0.8405$ dan $\mathrm{r}=0.8200)$.

Tabel 3. Nilai koefisien korelasi antar variabel faktor risiko pada skala Braden.

\begin{tabular}{lrrrrrr}
\hline \multicolumn{1}{c}{ Faktor Risiko } & $\begin{array}{r}\text { Persepsi } \\
\text { sensorik }\end{array}$ & Kelembaban & Aktivitas & Mobilisasi & Nutrisi & Gesekan \\
\hline Persepsi sensorik & 1 & & & & & \\
Kelembaban & 0.5127 & 1 & & & & \\
Aktivitas & 0.5520 & 0.2871 & 1 & & & \\
Mobilisasi & 0.4504 & 0.2733 & 0.9205 & 1 & 1 & \\
Nutrisi & 0.3840 & 0 & 0.6266 & 0.6309 & 0.5820 & 1 \\
Gesekan & 0.4336 & 0.1909 & 0.8405 & 0.8200 & &
\end{tabular}

\section{Pembahasan}

Hasil penelitian ini memberikan informasi tambahan tentang kejadian luka tekan pada lansia yang tinggal di rumah, khususnya tentang faktor risiko dominan tingkat keparahan luka tekannya. Berdasarkan Tabel 1, dapat diketahui bahwa kejadian luka tekan banyak terjadi pada lansia kelompok umur 74 tahun keatas (lanjut usia tua/ old), perempuan dan tinggal bersama keluarga besar. Hal ini sejalan dengan hasil penelitian di New England (UK) yang menunjukkan bahwa sebagian besar kejadian luka tekan yang ditemui pada saat pasien masuk rumah sakit terjadi pada lansia yang lebih tua dan tinggal di rumah (13). Hal ini menunjukkan bahwa pada lansia Indonesia yang tinggal di rumah, aktivitas yang menyebabkan adanya gesekan pada kulit perlu menjadi perhatian dalam menilai faktor risiko luka tekan. Diantara aktivitas tersebut adalah ibadah sholat dan kebiasaan duduk bersila di lantai. Sebagaimana yang diketahui bahwa aktivitas sholat dan duduk bersila yang berulang membawa risiko terjadinya gesekan pada bagian 
tubuh tertentu khususnya lutut dan mata kaki. Kondisi ini memperkuat dugaan penelitian sebelumnya yang memperkirakan banyaknya terdapat luka tekan kategori 1 pada lansia di masyarakat dikaitkan dengan kebiasaan sholat (khususnya gerakan sujud) dan duduk bersila di masyarakat Indonesia (8). Melalui penelitian ini dibuktikan bahwa walaupun lansia masih memiliki tingkat aktivitas dan mobilitas yang tinggi namun gesekan berulang dalam waktu yang panjang pada bagian tubuh tertentu dapat menimbulkan terjadinya luka tekan kategori 1. Oleh karena itulah banyak ditemukan luka tekan kategori 1 di area lutut dan mata kaki lansia di Indonesia. Hal serupa juga ditemui pada imigran muslim Bangladesh di Yunani (27). Melalui penelitian ini diperkuat bahwa luka tekan tidak hanya terkait penekanan pada kulit, namun penekanan minimal yang disertai gesekan juga akan menimbulkan luka yang dapat dikategorikan luka tekan (11). Dengan demikian diperlukan upaya untuk meminimalkan gesekan pada bagian tubuh lansia pada saat melakukan aktivitas rutin seperti sholat atau duduk, diantaranya dengan menghadirkan produk-produk penyangga yang mengurangi risiko gesekan.

Di sisi lain, penelitian ini menunjukan hubungan yang rendah antara variabel kelembaban dan nutrisi dengan keparahan luka tekan pada lansia di masyarakat. Meskipun demikian, belum tentu berarti bahwa kedua faktor ini tidak mempengaruhi keparahan luka tekan namun bisa saja diakibatkan karena kurang sensitifnya indikator variabel tersebut untuk diaplikasikan pada lansia di masyarakat. Sesuai dengan hasil penelitian yang dipublikasikan oleh R.J.G Halfens di tahun 2000 yang merekomendasikan bahwa perlu merumuskan ulang faktor risiko kelembaban dan nutrisi untuk meningkatkan sensitivitas dan spesifisitasnya (28). Selanjutnya, hasil analisis sekunder dari data retrospektif pasien yang dirawat di fasilitas perawatan akut yang berisiko mengalami ulkus tekan menunjukkan bahwa Skala Braden asli memiliki validitas yang tidak memadai untuk pasien perawatan akut dan disarankan untuk merancang skala prediksi risiko baru berdasarkan data mining. Penelitian yang dilakukan oleh Bergstrom menunjukkan hasil keandalan yang berbeda saat skala digunakan oleh perawat praktis berlisensi dan perawat terdaftar, dimana keandalan meningkat dari $r=0,83-0,94$ menjadi $r=0,99$ (29). Kemudian di tahun 2017, Chen H-L menyimpulkan bahwa Skala Braden memiliki validitas yang serupa dengan skala Braden asli untuk pasien rumah sakit namun reliabilitas antar penilai meningkat secara signifikan (30). Data-data ini menunjukan bahwa terdapat peluang untuk menyesuaikan indikator dan variabel faktor risiko kelembaban dan nutrisi skala Braden jika digunakan untuk penilaian lansia di masyarakat. Contohnya, untuk penilaian faktor nutrisi dapat dibandingkan kekuatan hubungan antara pengukuran nutrisi menggunakan indikator skala Braden, indeks masa tubuh dan instrumen Mini Nutritional Assessment dengan kejadian luka tekan.

\section{Simpulan dan Saran}

Faktor dominan yang mempengaruhi tingkat keparahan luka tekan pada lansia di masyarakat adalah faktor aktivitas, mobilitas dan gesekan. Sebaliknya, faktor kelembaban dan nutrisi memiliki hubungan paling rendah dengan keparahan luka tekan. Interaksi faktor gesekan dengan faktor aktivitas dan mobilitas sangat kuat mempengaruhi kejadian luka tekan pada lansia di masyarakat.

Saran dari penelitian ini adalah perlunya pengembangan alat-alat yang mengurangi gesekan pada bagian tubuh lansia pada saat mereka melakukan aktivitas yang berulang dan dalam waktu yang lama seperti pada saat sholat atau duduk bersila. Selanjutnya disarankan pula untuk mencari indikator penilaian faktor risiko kelembaban dan nutrisi yang lebih sesuai untuk diaplikasikan pada lansia di masyarakat.

\section{Ucapan Terimakasih}

Kami mengucapkan terimakasih kepada seluruh renponden yang tersebar di lima Kelurahan di Kota Bandung yang telah bersedia mengikuti penelitian. Selanjutnya terimakasih kepada Kementerian Riset, Teknologi dan Pendidikan Tinggi dan Universitas Padjadjaran yang telah mendanai kegiatan penelitian.

\section{Daftar Pustaka}

1. World OW. Ageing and health 2015. Switzerland; 2015.

2. MoHRo I. Analisis Lansia di Indonesia 2017. Health Mo Center for Data and Information; 2017.

3. Michel J-P SR. "Healthy Aging” Concepts and Measures. J Am Med Dir Assoc. 2017; 18(6):460.

4. Singh NS, Bass J, Sumbadze N, Rebok G, Perrin P, Paichadze N et al. Identifying mental health problems and Idioms of distress among older adult internally displaced persons in Georgia. Soc Sci Med. 2018; 211: 39-47.

5. Saquib N, Saquib J, Alhadlag A, Albakour MA, Aljumah B, Sughayyir M et al. Chronic disease prevalence among elderly Saudi men. Int J Heal Sci. 2017; 11(5): 11-6.

6. Randall WL, Bohlmeijer E KG. Storying Later Life: Issues, Investigations, and Interventions in Narrative 
Gerontology. New York: Oxford University Press; 2011.

7. Chatterji S, Byles J, Cutler D, Seeman T VE. Health, functioning, and disability in older adults--present status and future implications. Lancet. 2015; 385(9967).

8. Sari SP, Everink IH, Sari EA, Afriandi I, Amir Y, Lohrmann C, et al. The prevalence of pressure ulcers in community-dwelling older adults: A study in an Indonesian city. 2019; (December 2018): 1-8.

9. Landi F, Onder G, Russo A BR. Pressure ulcer and mortality in frail elderly people living in community. Arch Gerontol Geriatr. 2007; 44(Suppl 1): 217-23.

10. Jaul E C-MR. Systemic factors and mortality in elderly patients with pressure ulcers. Int Wound J. 2015; 12(3): 254-9.

11. EPUAP NPUAP. Prevention and Treatment of Pressure Ulcers: Quick Reference Guide. Pan Pacific Pressure Injury Alliance; 2014.

12. Gunningberg L, Stotts NA IE. Hospital-acquired pressure ulcers in two Swedish County Councils: crosssectional data as the foundation for future quality improvement. Int Wound J. 2011; 8(5): 465-73.

13. Corbett LQ Funk M, Fortunato G OD. Pressure Injury in a Community Population: A Descriptive Study. J Wound Ostomy Cont Nurs. 2017; 44(3): 221-7.

14. Khor HM, Tan J, Saedon NI, Kamaruzzaman SB, Chin AV, Poi PJ et al. Determinants of mortality among older adults with pressure ulcers. Arch Gerontol Geriatr. 2014; 59(3): 536-41.

15. Amir Y, Lohrmann C, Halfens RJ SJ. Pressure ulcers in four Indonesian hospitals: prevalence, patient characteristics, ulcer characteristics, prevention and treatment. Int Wound J. 2017; 14(1): 184-93.

16. Beerens HC, Sutcliffe C, Renom-Guiteras A, Soto ME, Suhonen R, Zabalegui A et al. Quality of life and quality of care for people with dementia receiving long term institutional care or professional home care: the European RightTimePlaceCare study. J Am Med Dir Assoc. 2014; 15(1): 54-51.

17. Chang SC, Shiu MN, Chen HT, Ng YY, Lin LC WS. Evaluation of care quality for disabled older patients living at home and in institutions. J Clin Nurs. 2015 ;24(23-24): 3469-80.

18. Meesterberends E, Halfens RJ, Spreeuwenberg MD, Ambergen TA, Lohrmann C, Neyens JC et al. Do patients in Dutch nursing homes have more pressure ulcers than patients in German nursing homes? A prospective multicenter cohort study. J Am Med Dir Assoc. 2013; 14(8): 605-10.

19. Schussler S, Dassen T LC. Care dependency and nursing care problems in nursing home residents with and without dementia: a cross-sectional study. Aging Clin Exp Res. 2016; 28(5): 973-82.

20. Carryer J, Weststrate J, Yeung P, Rodgers V, Towers A JM. Prevalence of key care indicators of pressure injuries, incontinence, malnutrition, and falls among older adults living in nursing homes in New Zealand. Res Nurs Heal. 2017; 40(6): 555-63.

21. Kwong EW, Pang SM, Aboo GH LS. Pressure ulcer development in older residents in nursing homes: influencing factors. J Adv Nurs. 2009; 65(12): 2608-20.

22. Kozier, Barbara, Glenora Erb, Shirlee Snyder and AB. Fundamentals of Nursing: Concepts, Process, and Practice. 8th ed. Upper Saddle Riveer: NJ: Pearson Education, Print.; 2008. p905-907.

23. Amir Y, Kottner J, Schols JM, Lohrmann C HR. Psychometric properties of the Dutch National Prevalence Measurement of Care Problems used to measure quality of pressure ulcer care in Indonesian hospitals. Adv Ski Wound Care. 2014; 27(8).

24. Halfens RJ, Meesterberends E, van Nie-Visser NC, Lohrmann C, Schonherr S, Meijers JM et al. International prevalence measurement of care problems: results. J Adv Nurs. 2013; 69(9): 5-17.

25. Braden BJ BN. Clinical utility of the Braden scale for Predicting Pressure Sore Risk. Decubitus. 1989; 2(3): 44-6.

26. BJ. B. he Braden scale for predicting pressure sore risk: reflections after 25 years. Adv Skin Wound Care. 2012; 25(2): 61.

27. Papadakis G, Zampelis T, Michalopoulou M, Konstantopoulos K, Rosenberg T CS. Prayer Marks in Immigrants from Bangladesh with Diabetes Who Live in Greece. J Immigr Minor Heal. 2016;18(1): 274.

28. Halfens RJG, Achterberg T Van, Bal RM. Validity and reliability of the Braden scale and the influence of other risk factors: a multi-centre prospective study. 2000; 37: 313-9.

29. Bergstrom N, Braden BJ, Laguzza A, Holman V. The Braden Scale for Predicting Pressure Sore Risk. Nurs Res. 1987; 36(4): 205-10. 
30. Chen H, Cao Y, Zhang W, Wang J, Huai B. Braden scale (ALB) for assessing pressure ulcer risk in hospital patients: A validity and reliability study. Appl Nurs Res [Internet]. 2017; 33: 169-74. Available from: http://dx.doi.org/10.1016/j.apnr.2016.12.001. 